\title{
Suomen kielen elki-sanue ${ }^{1}$
}

$E l k i$-sanue ei nykyisessä kirjakielessämme ole kovinkaan yleinen. Useimmin esiintyvät substantiivit elje ja elki, jotka ovat jokseenkin toistensa synonyymeja ja merkitsevät 'pahaa tapaa t. aietta t. tekoa, kujetta, kepposta, konnantyötä, koiruutta ; erikoista tapaa (varsinkin pahennusta herättävää), luonteelle ominaista piirrettä, oikkua'. Tavallisesti nämä substantiivit esiintyvät monikollisina: elkeet, eljet. Usein esiintyviä nykykielessämme ovat myös adjektiivit pahanelkinen ja häijynelkinen 'ilkeä, häijy, pahankurinen'.

Nykyistä käytäntöä valaissevat seuraavat Nykysuomen sanakirjasta (=NS) poimitut esimerkit: "Häijyt, katalat, pahat, rumat elkeet. Vainolaisten elkeet. Konnan, noitien, paholaisten elkeet. Hän on heittänyt entiset elkeensä. Pahanelkinen ihminen."

Yleisesti tarkastellen elki-sanue on kielessämme negatiivisesti värittynyt, ts. siihen kuuluvia sanoja ja sanontoja käytetään useimmiten jonkin huonon t. vastenmielisen ominaisuuden, teon t. toiminnan kuvaamiseen.

\section{Elki-sanueen esiintymisestä vanhoissa sanakirjoissa}

SCHRODERUKSEN sanakirjasta (1637) elki-sanue puuttuu kokonaan. JUSLENIUKSEN sanakirjassa (1745) esiintyvät substantiivi elki, eljen 'indoles, mos; kynne, sed' ja adjektiivi elkinen, elkisen 'indole, moribus praeditus; af sådant kynne' ynnä lisäksi elkiwallainen 'effrenus ; osedig, sielfzwåldig', elkiwallaisus 'effrenatio, nequitia; sielfzwåld' ja elkiwallaisesti 'effrenate; sielfzwåldigt'.

GANANDER (käsikirjoitus 1787) mainitsee sanat elki, elkiä, elkiästi;

1 Kirjoitus perustuu tekijän laajempaan tutkielmaan "Elki- ja ilkeä-sanueet suomen kielessä" (v. 1962), jota käsikirjoituksena säilytetään Turun Yliopiston suomen kielen laitoksessa. 
pahan t. häjyn elkinen ja edelleen elki-paha, elkiwalda, elkiwallainen, elkiwallaisesti, elkiwallaisuus sekä niiden käytöstä mm. seuraavat esimerkit: "Emän Eljet Tyttärellä, pojalla isäns asumet. Emännäll' on Eljet kolmet. Oudot onnen Eljet. Eliet ilkiät, juonet julmat. Ilkiät ihmisen eliet- 1. lihalliset lijkutuxet. Me olemma elkiät ja kijttämättömät ihmiset. Itze naiwat Elkiwallat. Elkiwaldaisesti syndiä tehdä kjeltään. Ej hän hänen elkiwallaisuttansa sallinut."

RENVALLin sanakirjassa (1826) on mm. elki, eljen tav. mon. eljet 'mores inveterati, vivendi modus, ingenium naturae max. malum; Laune' ja elki-walta 'licentia', elki-paha 'valde malitiosus 1. pravus' sekä lisäksi elkï̈ '(male) moratus, ingenii mali ; launig, übellaunig', pahan elkiä 'male moratus, indolis pravae ; ungesittet', pahan elkinen 'der übellaunig ist' ja elki ästi 'malitiose, turpiter'.

HelenIUKSÉN sanakirja (1838) esittää seuraavat: eljeh, elken; elki, eljen, mon. eljet 'vana, lynne'; elkiwalda ja elkiwaldainen ; elkiä, elkinen 'illa sinnad'; pahan elkiä t. elkinen 'elak, stygg' ja elkiästi 'illa, styggt, nedrigt, (lågt)'.

$E l k i$-sanue esiintyy sitten melko laajana esim. WALLINin, EuRÉNin ja Ahlmanin sanakirjoissa. EurÉn (1860) mainitsee mm. verbit ellentä̈̈, elkentä̈ 'begripa'.

LöNNROT käsittelee sanakirjassaan elli-sanuetta jo varsin laajasti. Elki, eljen hän selittää 1. 'sinnesart, lynne, sed, vana; egensinne, nyck, kynne, okynne, upptåg' ja 2. '= ilki'. Hän esittää myös synonyymiparit elkeys $=i l k e y s$ ja $e l k e \ddot{a}=i l k e \ddot{a}$. Tämän lisäksi Lönnrot mainitsee mm. verbit eljehtiä 'ha skälmstycken l. upptåg för sig' ja el.jentä̈a 1. elkentä̈̈ 1. ellentä̈̈ 'inse, fatta, förstă, begripa'. Hänellä on esimerkkilauseena: "Mies saapi nyt eljentä̈̈, mutta lapsi vielä häiretköön 'en man måste nu finna sig, men ett barn må ännu vara rådvill'."

\section{Vanhan kirjakielen ja kansanrunouden edustus ${ }^{2}$}

Vanhasta kirjakielestä löytyy runsaasti esimerkkejä elki-sanueen käytöstä. Näissä esiintyvät ensinnäkin substantiivi elki ja yhdyssanat pahanelkisyys sekä elkivalta, elkivaltainen, elkivaltaisuus. Elkiä-

${ }^{2}$ Esimerkkiaineisto on kerätty toisaalta alkuperäisistä lähteistä, toisaalta Tutkimuslaitos "Suomen suvun" kokoelmista. Mikäli jälkimmäisessä tapauksessa poiminnon lähdeviitteessä ei ole esiintynyt sivunumeroa, se myös tämän kirjoitelman asianomaisesta kohdasta puuttuu. 
adjektiivi on harvinaisehko, mutta sen sijaan hyvin lukuisissa poiminnoissa esiintyvät jokseenkin sen synonyymeina pahanelkinen, häijynelkinen, sen elkinen. Kansanrunouden esimerkit rajoittuvat yksistään elki-substantiiviin.

\section{elki}

Ensimmäisessä poiminnossa, joka on peräisin Agricolan tekstistä, elki-sanan voi katsoa merkitsevän lähinnä '(ilkeää, pahaa) aietta t. juonta', mahdollisesti myös 'neuvoa': "HerRa, sine cuulet heiden pilcans, ja caiki heiden aijattoxens minua wastan, Minun wastanseisoiadhen hwlet, ia heiden elghiens minua wastan iocapäijue." (Mikael Agricolan teokset $=$ Agr. I s. 175, Jer. val. 3: 61-62.) Myöhempien raamatuntekstien vastaavassa kohdassa esiintyy neuvo t. aie.

Seuraavissa vanhan kirjakielen esimerkeissä elki-sanan merkitys on 'pahuus, häijyys ; ilkityö, kuri, juoni': "Cuin kirjain sias pidhetän, / Cortid, corghot, mailman eljed." (Hemminki Maskulainen, Vanhain Suomen maan Pijspain ja Kircon Esimiesten Latinan kielised laulud, 1616, s. 111.) ; "Näistä me näemme Perkelen pahat juonet ja eliet, _ _ _." (Laurentius Petri, Christillinen Saarna Engeleistä, 1670.) ; "Tohdimme kyllä ylpiästi nijtä öykätä ja kerscata, ettei ne ole pahat juonet ja häijyt eljet, _ _ _." (Jaakko Raumannus, D. Martinus Lutheruxen Catechismus, Se Suurembi, 1674, s. 105.); "_- _-, mutta myös caickinaisilla häijyillä eljillä ja juonilla, sitä yxiwacaista Yhteistä Cansaa siehen samaan (vihollisten suojelemiseen) yllyttäwät." (Grotenfelt, Suomenkielisiä historiallisia asiakirjoja s. 156.)

Kaikissa edellä esitetyissä vanhan kirjakielen esimerkeissä elkisanaa on käytetty monikollisena. Kansanrunouden poiminnoissa on yksi, jossa esiintyy elki-sanan yksikkö. Sanan merkitys on kaikissa 'paha, häpeällinen teko, ilkityö', jopa voidaan ajatella sen merkitsevän 'syntiä'. "Iteppäs lienet Herra Jesus, / Kus miun elkeni sanelit."

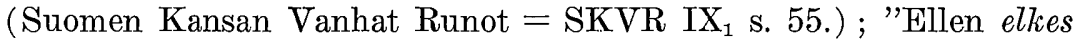
sanele." (SKVR IX $\mathrm{I}_{1}$ s. 131.) ; "Anna mennä muille maille / elkeäns ä piilomahan, / töitänsä häpelemään." (SKVR X $\mathrm{X}_{2}$.)

elkivalta, -valtainen, -valtaisuus

Substantiivi elkivalta esiintyy seuraavissa 1600-luvulta peräisin olevissa poiminnoissa merkityksessä 'pahuus, häijyys, ilkeys, ilkivalta, 
ilkimielisyys': "- _ - waicka se Pawin willityxellä ja elkiwallalla oli täytetty;" (Kircko-Laki Ja Ordningi, suom. 1688; Agricolasta Juteiniin s. 180.) ; "Ja perustetut Caupungit, / Alas sai elkiwalda." (Historiallinen arkkivirsi 1600-l. lop.; Vir. 1935, s. 387.)

Edellisestä johdettu adjektiivi elkivaltainen 'paha, häijy, huono, ilkeä, ilkivaltainen' ja substantiivi elkivaltaisuus 'pahuus, häijyys, ilkeys, ilkivaltaisuus' esiintyvät vanhassa kirjakielessä melko yleisesti. Esimm. "Pinehas se elkiwaldainen, hirmuisel surmal sodas teloitettija, _-_." (A. M. Pacchalenius, Cantio Cygnea, 1667.) ; "Jos myös jocu Cruunun-Palwelia löyttäisin nijn elliwallaisexi, että hän annais ylitzenpuhua itzensä, _ _ _.." (Cuning: sen Maij: tin Armollinen Asetus, Arpain uloslähettämisestä ja candamisesta ymbärinsä Maacundia. Annettu 1743, Präntätty 1756.) ; "Taicka ylpeydest, costonpyynöst, ja elkiwallaisudest, ilman yhtään tarwetta andawat itzens tappeluxijn, eamppauxijn, ja muihin waaroin, joista he kyllä hywin saisit poisolla." (Abraham Ikalensis, Christillinen Rwmijn Saarna, Ylitze Sen Cunniallisen ja Hywinoppeneen Her Johannexen Matthiae Collinuxen, 1671.) ; "Monen Synnin muisto cauhista minua, cuin hilimättömäs nuorudeni Elkiwallaisudesa tehnyt olen." (Gabr. I. Tammelinus, D. Johan Gerhardin - - Pyhät Tutkistelemukset, 1688.)

\section{elkï̈}

$E l k i \ddot{a}$-adjektiivi esiintyy yhdessä Raumannuksen tekstin esimerkissä yhdyssanassa pahanelkï̈, jonka merkitys on 'paha, häijy; rikkonut, syntinen ; ilkeä, ilkimielinen': "_—— emme näitä saarna Christityille, waan caickein enimän pahanellijlle, joille Duomari, Wahtimies ja Böweli saarnaman pidäis." (Jaakko Raumannus, mt.). Tämän lisäksi elkiä esiintyy kahdessa 1700-luvun esimerkissä 'pahan, huonon, ilkeän' merkityksessä: "Jollet sinä nyt, rakas sielu! tahdo, että minun pitä hylkämän sinua, nijnkuin yhtä elkiätä ja uskotoinda porttoa, nijn sinun pitä lakkaman sijtä hulludesta." (I. Grape - Joh. Qvirsfeld, Taiwallinen Yrttitarhan-Seura, 1779, s. 311.); "Ajattele ainoastans, kuinga elkiästi ja häpiällisesti sinä olet usiasti minun Pyhää Nimee, JESus, maininut." (Ibid. s. 320.)

elkinen, -elkisyys

Adjektiivi elkinen esiintyy vanhassa kirjakielessä hyvin usein. Sitä ei kuitenkaan käytetä yksinään, vaan yhdyssanan tai vakiintu- 
neen sanaparin jälkiosana: paha(n) elkinen (pahan elkinen), häijynelkinen (häijyn elkinen), sen ellinen.

Useimmiten vanha kirjakieli käyttää paha(n) elkinen-adjektiivia tarkoittamassa 'pahaa, häijyä, huonoa, syntistä, pahanilkistä, ilkeää'. Jo Agricolan teksteissä tämä adjektiivi esiintyy monta kertaa, esimm. "Auta, ette me, aijna walwoijsim, ia henen paha elkiset neuuons caualat aijatoxens, petteweijset aijwotuxens, ia couckuns, ia moniharaijset constins, wisusta cawattaijsim." (Agr. I ss. 489-490) ; "Sille nin quin Perkele canaluxella Inhimisen petti ia cadotuxeen saattoi Nin Jumala taas tachtoi sen pahanelkisen constin caualuxila tacaperin aia." (Agr. II s. 9) ; "He tichterauat Coirutta, ia sala sen piteuet, he ouat pahaelkiset ia piteuet caualat Joonet." (Agr. III s. 299).

Pahanelkinen esiintyy myös useissa 1600- ja 1700-luvuilta peräisin olevissa esimerkkipoiminnoissa: "—_ - me olem ollet syndiset, wäärintekiät, pahan elkiset, Jumalattomat, __ _." (J. P. Finno, Yxi wähä Rucous Kiria, 1583, s. 153.) ; 'Näin nämät pahanelkiset ia Vleocullatut Phariseuxet pilcavat ia panettelevat meidän HeRra Jesusta Christusta, ia _____.". (Eerik Sorolainen, Postilla II s. 895.) ; "Sillä wijsaus on parembi cuin harnisca, waan pahanelkinen turmele paljo hywä." (Biblia 1642, Saarn. 9: 18) ; "_—— Sijnä lulos että heidän cummingin sitä wiatoinda JEsusta, ennen piti tahtoman päästä, cuin sitä pahanelkistä, ja julkista Murhajata Barrabast; _ —_." (Abraham Ikalensis, Jesuxen Christuxen Meidän ainoan wälimiehem Kärsimisen historia, 1659, ss. 108-109.) ; "_—— Minä wastaisin: sinä pahanellinen, ei tämä tusca wielä mitän ole sen tuscan suhten cuin Helwetisä sinun päälles warto." (Abraham Achrenius, Hengelliset Historiat 1761, s. 121).

Häijynelkistä käytetään vanhassa kirjakielessä pahanelkisen synonyymina, ja senkin merkityksiä ovat siis 'paha, häijy, huono, pahanilkinen, ilkeä'. Esimerkkejä on kuitenkin suhteellisen niukasti: "Sang'en harwoin se tapahtu, että sencaldaiset häijyn elkiset Ihmiset oikian ja hywän Cuoleman saawat: _ _ _ _.." (Jaakko Raumannus, mt. s. 60) ; "Sillä eij hän tahdo yhtän Tyranni ja häjyn elkistä täsä wirasa pitä, ____." (Ibid. s. 68) ; "Muutamilda Jumalattomild ja häijynelkisild Ihmisildä." (Kircko-Laki Ja Ordningi, 1688, s. 157).

Sen elkinen näyttää rajoittuneen ensi sijassa lakikieleen, koskapa kaikki poiminnot ovat peräisin lakitekstien suomennoksista. Seuraa- 
vissa esimerkeissä tämän ilmauksen lähin vastine olisi ehkä 'sen kaltainen, sellainen'. Joka tapauksessa tähänkin useimmiten liittyy jotakin huonoa, pahaa, ilkeätä, vastenmielistä. "Joca sen caldaisia miehiä (murhaajia yms.) huonesens otta, holhoapi eli koriapi tietäns eli tahdhollans, olkan se nijn hÿuä, quin nekin, sen elkitzet cutzutan Metzä warkaxi eli Meri Röäuärixi." (Martin maanlainsuomennos; Suomen kielen muistomerkkejä = SKM II s. 134) ; "Noitu mies miehen eli waimon, waimo waimon taicka miehen, nijn että mies eli nainen sijtä cuoleman saapi: Mistatcaan hengensä sen elkisestä pahasta työstä." (Kollanius, SKM III, 1 ss. 184-185) ; "Soima mies toiselle sen elkistä työtä, Nijn pitä hänellä siehen, cahdhen miehen todhistoxen oleman:" (Kollanius, SKM III, 2 s. 456).

Vanhasta kirjakielestä esitettäköön vielä pari esimerkkiä, joissa esiintyy substantiivi pahanelkisyys 'ilkeys, ilkivaltaisuus, pahanilkisyys, elkivaltaisuus': "Silmät catzocon senpälle jotas puhuttelet, mutta lembiät ja yxikertaiset, eij häpemättömyttä eli pahanelkisyttä osottawaiset." (Erasmus Roterodamus, Cullainen Kiria Nuorucaisten Tapain Sijwollisudest, suom. 1670, s. 178) ; 'Jos jocu täysikäinen ylösotta, muutta eli poisheittä pyykit ja rajakiwet, eli muut eroitusInerkit, pahanelkisydestä eli itzewaldaisudesta; olcon cahdenkymmenen talarin sacon alainen." (Ruotzin Waldacunnan Laki 1734, Präntijn annettu 1759, s. 68).

Edellä käsitellystä vanhan kirjakielen edustuksesta voi todeta, että varsinkin substantiivien elje ja elki sekä adjektiivien pahanelkinen, häijynelkinen ja sen elkinen käytöstä esimerkkejä on runsaasti. Useimmiten nämä kaikki tarkoittavat jotakin negatiivista asiaa t. ominaisuutta.

\section{Elki-sanueen esiintymisestä nykyisessä kirjakielessä ja murteissa ${ }^{3}$}

Nykyisessä kirjakielessämme elki-sanueen käyttöä ei voi pitää kovin yleisenä. Kuitenkin NS mainitsee substantiivit elje ja elki sekä adjektiivin -elkinen.

\footnotetext{
${ }^{3}$ Murre-esimerkit on kerätty etupäässä Turun Yliopiston suomen kielen laitoksessa olevista Sanakirjasäätiön kokoelmien mikrofilmijäljennöksistä. Esimerkit on asetettu keruupiirijärjestykseen ja niiden tarkekirjoitusta on karkeistettu. Pitäjännimistä on käytetty Vir. 1950 ss. $427-428$ julkaistuja lyhenteitä.
} 
Suomen murteissa elki-sanueen piiriin kuuluvia ilmauksia käytetään suhteellisen runsaasti. Murteissa esiintyviä substantiiveja ovat ensinnäkin elje, elki ja elju sekä lisäksi eljuttelija, elkimaakari, eljutteleminen ja elkisyys. Murteiden käyttämiä adjektiiveja taas ovat eljellinen, eljekäs, eljuinen ja lisäksi karitiiviadjektiivi eljetön sekä poss. adj. -elkinen. Näiden lisäksi murteissamme esiintyvät vielä adverbi elko (vain yksi esimerkki) sekä verbi eljutella.

elje, elli

Sekä kirjakielessä että varsinkin murteissa nämä sanat esiintyvät usein toistensa synonyymeina, joten on aiheellista käsitellä niitä tässäkin yhdessä. Tavallisimmin käytetään monikollista muotoa elkeet t. (harv.) elje(e)t.

NS selittää substantiivin elje (tav. mon.) kahdella tavoin: 1. 'paha tapa t. aie t. teko, kuje, ilve, juoni, metku, kepponen, konnantyö, konnankoukku, koiruus', esimm. "Häijyt, katalat, pahat, rumat elkeet. Vainolaisten elkeet. He tunsivat raudan tavat sekä teräksen luonnon ja elkeet. (Paulah.)"; 2. 'ele', esimm. "- - naurahti pilkkailevin elkein. (Alkio) ; - - kotona sitten kysyivät nauravin elkein, että mikäs tuollakaan on vikana. (Seppänen)"

$E l k i$-substantiivin NS selittää seuraavasti: 'erikoinen t. huomiota kiinnittävä tapa t. temppu, vars. pahennusta herättävä, elje'. Esimm. "Emän eljet tyttärellä. (SL) ; Oli hällä toki elki pieni, / tapa urohien muiden mukaan: / Pyhäsiltä pesällistä kaksi / poltti lehteä hän venäläistä. (Kivi) ; Sinä peijooni! aina valmis koiranelkiin. (Kivi) ; Lienet itse Herra Jeesus, / kun mun elkeni sanelit. (Kant.)"

Murteissa elje ja elki esiintyvät yleensä monikollisina, samaa merkitsevinä. Ensinnä käsitellään ryhmä, jossa sanan merkitys on 'paha tapa, aie t. teko ; kuje, ilve, juoni, metku, kepponen, konnantyö, koiruus'. Esimm. "Aatu meni pahoil eljillään ja pani tupakkii muorin kaffepannuun, ku muori oli ulkona" (Viht) ; "Tee elkï̈ elläisäs (jakaa kurejansa), siittä miästä mainitaan" (MetM) ; "Oli sillä elkeet, kun vei viilin kuoret pöyäle ja piimän söi ite" (Kih) ; "Sillä on niin pahat elkeet (t. eljeet) ja meininkit" (Hat) ; "Se toisten renki ei osa muuta tehlä, kun näytellä niit elkiäh" (Eli) ; 'Mutta hetpää alako markkinaruuna elekijjää ja konstijaa näötelä ku uutee paekkaa joutu, vaekka markkinoela olj olla nii laohkee loatujne" (RanS) ; "Sill on aina sellaasia elekehiö" (Jal). 
Seuraavat murre-esimerkit liittyvät hyvin läheisesti juuri esitettyihin, jopa niin, että tarkan rajan vetäminen niiden välille on mahdotonta. Tähän ryhmään valitut esimerkit kuitenkin pyrkivät osoittamaan murteiden tapaa sanoa jotakin ihmisen koko luonteesta. Sanan merkityksiä tässä tapauksessa ovat: 'erikoinen t. eriskummainen tapa t. temppu (vars. pahennusta herättävä) ; luonteelle ominainen piirre, oikku'. Esimm. "Kyl sil pojal on niin pahat elkeet jo piänenä, et mitä isona ollenkaan onkan" (Num) ; "Pirun elkeet sill on ain kun Takalan katill" (Somero); "Hänellä ei o ollenkam miähen elkeitä (tapa, käytös)" (Oriv) ; "Surella on suren elkeet (pahat ajatukset)" (Tyrvää) ; "Isän tavat pojalla, äitin eljet tyttärellä" (Harl) ; "Jo ny elekeesä otti ku rupes varastammaan" (Äht) ; "Kyllähän äiteensä elekehet taitaa (inhottavat temput)" (Isoj) ; "Sillä poijall on niin huonoja elekihijä, isänsä elekehet" (Kuri).

Tarkasteltaessa elje- ja elki-sanojen käyttöä murteissa huomataan, että ne liittyvät jokseenkin aina henkilöön. Mainitut substantiivit ilmaisevat jo sinänsä yleensä negatiivista ilmiötä tai ominaisuutta, mutta usein käytetään vielä vahventavia sanoja: paha, kaikki, ilkeä tms. Esimerkeistä päätellen elje ja elki esiintyvät pääasiassa länsimurteissa. (Ks. karttaa.)

NS esittää elje-sanalle myös merkityksen 'ele', kuten edellä on mainittu. Käsitellyssä murreaineistossa on esiintynyt ainoastaan yksi vastaavanlainen tapaus. Tämä on Hausjärveltä peräisin oleva, tosin epävarma tieto, jonka mukaan elkeet merkitsee 'eleet, merkit': 'Sill on semmoset elekeet" (Haus).

Tässä yhteydessä lienee aihetta tarkastella vähän laajemminkin suhdetta elje t. elki ele, koska se omalta osaltaan valaisee juuri edellä esitettyä käytäntöä. Virittäjän palstoilla on aikoinaan käyty keskustelua siitä, kuuluvatko nämä sanat yhteen vai onko ne pidettävä toisistaan erillään.

"Eleet ja elkeet näkyvät helposti sekaantuvan", kirjoittaa E. A. TuNkelo (Vir. 1909 s. 139). Hän on kuitenkin sillä kannalla, että ne olisi yleiskielessä pidettävä erillään. Vastatessaan esitettyyn kysymykseen Tunkelo selvittelee eleet elkeet -suhdetta uudelleen Virittäjässä v. 1912 (ss. 153-155). Hän antaa esimerkkejä kummankin käyttötavoista ja toteaa samalla, että varsinkaan murteissa ei rajan vetäminen näiden sanojen välille ole kovin helppoa. Monissa tapauksissa niiden käyttö on kyllä selvärajaista, mutta löytyy myös run- 


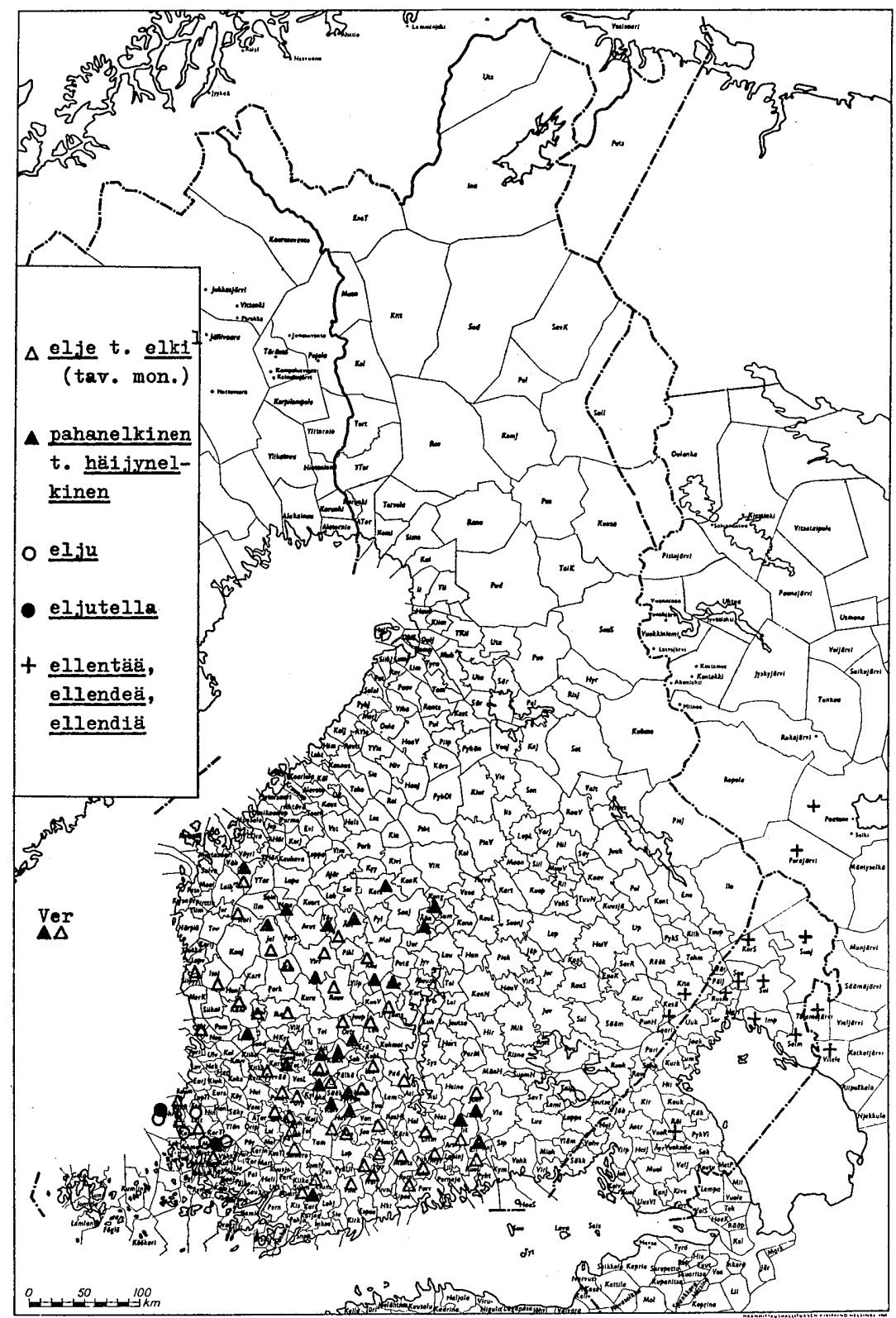

${ }^{1}$ Kartassa mainittujen lisäksi on elje-, elki-sanasta osittain epävarmoja tietoja seuraavista pitäjistä, kustakin yksi: Harl Räi Sor Ilo RanS Puo RisJ. 
saasti esimerkkejä, joissa eron tekeminen on vaikeaa. Tunkelo antaa joitakin murre-esimerkkejä, joissa ele-sanan merkitys on jokseenkin sama kuin 'elki'.

Sellaisia esimerkkejä voi murreaineistosta poimia enemmänkin. Seuraavassa esitettäköön muutamia Tunkelon mainitsemien lisäksi: "Kyllä tolla poijjaall om monellaisija elleitä" (Luo) ; "Sillä on pahat eleet" (Pad) ; "Ompas sillä eleet ja pelit ja kujeet" (Jäms) ; "Mikä nuaren kloppie eleetä (juonia, kujeita) tiätää, mitä ne kulloonkij jauhaa?" (Lapu) ; "Mullakin sellaasija kloppijen elehijä oli, ei sunkaam flikkatenavap pruukaas sellaasta teherä (heitellä lingolla kiviä)" (Nmo); "Saas nähä mikä tuosta pojasta tulee, sillon vähän semmoset huonot eleet" (Perh).

Näistäkin esimerkeistä ilmenee, että ele-sanaa käytetään murteissa melko yleisesti samassa merkityksessä kuin 'elje, elki'. Toisaalta taas elje t. elki voi esiintyä tarkoittamassa ele-sanaa. (Vrt. ed.) Kuitenkin jo RENvalc tekee eron näiden sanojen kesken, kuten Tunkelo vastauksessaan huomauttaa.

NS mainitsee ele-sanan (us. mon.) merkityksinä seuraavat: 'ruumiin eri osien, vars. käsien, kasvojen ja pään liikkeistä mielialan ilmaisijoina ; psyk. ilmaisuliike' ja toiseksi: eleillä, eleille 'elossa, liikkeellä'. Sanakirjat siis tekevät selvän eron eleet- ja elkeet-sanojen kesken, mutta käytännössä kumpaakin ilmausta käytetään osittain toistensa merkitystehtävissä. Saattaa olla, kuten E. A. Tunkelo mainitsee: 'Kuitenkin näyttää siltä, että 'eleiden' erikoistuminen tarkottamaan ruumiin eri osain ja elinten liikkeitä mielialain ilmeinä kuuluu etupäässä uuden kirjakielen itsetietoisiin täsmällistymispyrkimyksiin." (Vir. 1912 s. 155.)

\section{Johdoksia ja yhdyssanoja}

Käsitellyssä murreaineistossa eljellinen-adjektiivi mainitaan vain Oulun pitäjästä, ja melko harvinainen on myös sen synonyymi eljekäs. Kumpikin merkitsee 'pahan tapainen, kurikas, juonikas'. Samoin jokseenkin harvinaisina tavataan murteissa adjektiivit eljetön ja elkeetön 'elkiä vailla oleva'. Tietoja on vain Saarijärveltä (elekeetön), Keuruulta (äljetön) ja Oulun pitäjästä (eljetön).

Adjektiivi -elkinen ei esiinny yksinään käytettynä, mutta sen avulla muodostetut yhdysadjektiivit sen sijaan ovat yleisiä sekä kirjakielessä että murteissa. Näin muodostettu adjektiivi on jokseenkin 
aina pahan- t. häijynelkinen; ne esiintyvät kyllä myös erikseen kirjoitettuina. NS tyytyy tosin vain mainitsemaan nämä adjektiivit, ja niinpä seuraavat esimerkit ovatkin kaikki peräisin murteistamme. Levinneisyys murteissa käy selville kartasta. Esimm. "Älä me vallan liki sitä hevosta, seo vähä pahanelkine" (Sääk) ; "Ne molemmat herrat on nii pahanelkisii" (Jaal) ; "Se äit ol paha elekine eikä lastu kauvaks kannoltaa lennä" (Kars) ; "Se on niin pahanelekinen vekara, nottei sitä viitti kattellakkaa" (JaI) ; "Kyllä niit on tualla kirkonkyläs ollu häjynelikisijäkim miähijä" (Nmo); "Kyllä tua tenava on pahanelkinen" ('Töy).

Substantiivi -elkisyys esiintyy vain Ähtärin murre-esimerkissä: "Pahanelkisyyvessään tyäntivät veneen tuulen vietäväksi" (Äht). Todennäköistä kuitenkin on, että tämän tapainen käyttö on murteissakin huomattavan runsasta. Vastaava adjektiivihan on suhteellisen yleinen, ja substantiivikin esiintyy myös mm. vanhassa kirjakielessä ; vrt. ed.

Pahantapaista ihmistä tarkoittamassa käytetään murteissa myös substantiivia elkimaakari, esim. "Se on aika elkimaakari" (Ren).

Vahvennusadverbina käytetty elko näyttää olevan perin harvinainen. Tutkitussa murreaineistossa se esiintyi ainoastaan kerran: "Eleko elävältä meinas' minut tappoa (leikill.)" (SaaJ). Tässäkin leikillisessä lauseessa eleko saattaa osittain olla alkusoinnuttelun aiheuttama. Toisaalta elko-adverbi on kuitenkin hyvin ymmärrettävissä vastaavanlaisen, mutta nykyisin huomattavasti enemmän käytetyn $i l k o$-adverbin vastineeksi.

elju johdoksineen

Sanojen elje ja elki synonyymina esiintyy suppealla alueella Turun ympäristössä murremuoto elju. Tätä käytetään varsinkin puhuttaessa jonkun omituisista tavoista, päähänpistoista tai itsepäisyydestä. Esimm. "Semse paha elju (tark. etup. itsepäisyyttä) täyty otta pois" (Lait) ; "Oi voi snu eljujas" (PyhM) ; "Men pois paikkunnalt eljunes" (PyhM). (Ks. karttaa.)

Melko harvinaisena tavataan adjektiivi eljuinen, jonka merkityksiä ovat: 'pahan tapainen, juonikas, kurikas'. Esimm. "Se oo ni eljune ('pahan kurinen ihminen' tai myös 'vikuri eläin')" (PyhM) ; "Se o nii paheljune ihmine, ei sen kans mielelläs vihohi men" (Kalan).

$E l j u$-substantiivin johdos on myös verbi eljutella 'tehdä kiusaa, vastustella, oikutella'. Esimm. "Juur ai se poja raat eljuttele (on 
oikullinen)" (Myn) ; "Joltes lak eljuttelemast ni mä anna sul selkkä" (Myn); "Se oo semne et ai eljuttele" (PyhM); "Pakka aevottaisi vähä eljuttelema" (PyhM). (Ks. karttaa.)

Edellisestä johdetut substantiivit eljutteleminen ja eljuttelija näyttävät olevan harvinaisia. Edellinen mainitaan vain Mynämäeltä ja jälkimmäinen samoin ainoastaan kerran: "Siit tul semne eljuttelia (kiusallinen juonittelija, pahan oikkuinen kiusaaja)" (PyhM).

\section{Lähisukukielten ja lapin edustus}

Karjala-aunuksessa, lyydiläismurteissa ja vepsässä esiintyy sanoja, joiden ilmeisesti voi katsoa kuuluvan yhteen suomen elkisanueen kanssa. Muissa lähisukukielissä ei tämän sanueen äänteellisiä vastineita liene, mutta sen sijaan lapin kielessä on verbi $œ \bar{l} j e$ - 'muistaa, ymmärtää', joka kuulunee tähän yhteyteen. Tässä esitettävät tiedot perustuvat ensi sijassa sanakirjaedustukseen.

Karjalan kielestä tunnetaan verbi ellentää 1. ellendeä 1. ellendiä, jonka merkityksiä ovat: 'ymmärtää, älytä, oivaltaa, huomata, aavistaa'. Esimm. "Kyllä mie ellennän" ( $\operatorname{Imp})$; 'Mänebä tiijä, ellennetääkö Helsingin herrat neńjie karjalazie sanoi (= näitä karjalaisia sanoja)" (Sui) ; "En ellendä ni midä" (SuoJ); "Emokasta neuvoo, emoton ellenti" (KorS) ; "Toinemba sen ellendää vaik et sanois" (KorS) ; "Emäkästä kun neuvotaan, niin emätön ellentäköön" (Soa) ; "Minä katšo ellendin, hot' ei sidä sanonnuh" (Salm) ; "Mie en ellendäd ńi midä" (Porajärvi). Joitakin yksinäisiä tietoja ellentää-verbistä on suomestakin (Räi Kesä Kite). (Ks. karttaa.)

Karjalan kielessä esiintyvät myös verbit elgovuo 'oppia, viisastua' ja elgovuttoa 'opettaa, viisastuttaa'. Esimerkit ovat Suojärveltä: "Elgovui roadamah. Lapsed mi eletäh (= iän karttuessa) se elgovutah."

Edellä esitettyihin verbeihin liittyvät läheisesti karjala-aunuksessa tavattavat substantiivit ellendüs 'oivallus', ellendändä, ellendämine ja elgominen 'ymmärtäminen' sekä elgo, elgu 'äly, järki, ymmärrys'. Suistamolaisessa itkuvirressä esiintyy substantiivi elgońe 'mieliala, luonto': "nüudü elgozie" 'semmoista mielialaa'. Esimm. "Hänen elgomizien täh ükskai en usko" (Säämäjärvi) ; "Sil on olluh täüz elgo peäs" (SuoJ) ; "Kell eluo, sill i elguo" (Säämäjärvi).

Karjala-aunuksessa esiintyvät adjektiivit elgońi, elgohińi, -elgoine, elgovuz, elgožu ja ellokaz merkitsevät kaikki 'älykäs, ymmärtäväinen, järkevä, viisas'. PoHJanvalo mainitsee Salmin murteen sanakirjas- 
saan 'ymmärtäväisen' synonyymiksi : ellettšy. Esim. "Hot' meijjän brihattšu on vie pieńi vai kuitengi häi on ylen ellettšy." Suojärveltä taas on peräisin tieto, jonka mukaan ellat't'šu merkitsee 'älyniekkaa'. Samasta pitäjästä mainitaan vielä: ellotoi 'älytön' ja adv. ellottomuten 'koska oli ellotoi'. Esim. "Ellottomutem muga roadoi."

Tämän käsittelyn piiriin kuulunevat vielä karjalan verbit elgiändyö ja elgavyö 'kyllästyä', elgäillä 'iljeksyä' sekä elgäitteä, elgävyttïa ja ellätä 'kyllästyttää, inhottaa, etoa, ellottaa, tympeyttää'. Esimm. "Täz eloz terväh elgiändyy" (Salm) ; 'Elgävüi kalasüömiziz" (SuoJ) ; "Vähäizel elgäili, ga ükskai pidi mennä sille (vanhalle vaimoksi)" (Säämäjärvi).

Lyydiläismurteissa esiintyy verbi elgeda, elgett.A; prees. el'gèndän, elgendan 'ymmärtää'. Esim. "Poig on vie ižan tagut, nuoŕ, ei elgenda ńi mida (= Poika on vielä isän turvissa (takana), nuori, ei ymmärrä (elämästä) mitään)"."

Myös vepsässä on verbi $e l^{\prime} g e t a, e l^{\prime} g e n d a n$, joka merkitsee 'ymmärtää'. Lauri KeTTUNEN mainitsee elgendan 'saan aru, mõistan' ja lisäksi adjektiivin öugotō (<*elkettoin) 'kõlvatu inimene'. Esimm. "Ebad elgenda 'nad ei saa aru'. Tšortteap kehe sä läksīd' öugotō 'kurat teab kelle sarnane sinust sai, kõlvatu'." 5 Ö ugotō 'kelvoton, kunnoton' on etelävepsäläinen muoto. Pohjoisvepsässä sama adjektiivi on muodossa elgetoi, ja sen merkitys on lähinnä 'älytön'.

August AHLQvisT mainitsee sanat elgeitelob, elgensõitab 'känna ekel t. vämjelse ; ilettää' ja elgetõin 'oförståndig, dum'. ${ }^{6}$

Y. H. TorvoneN yhdistää elki-sanueeseen myös lapin verbin $\nsim i ̄ j e-$ 'muistaa, ymmärtää', jonka hän arvelee lainautuneen sinne karjalaaunuksesta. ${ }^{7}$

\section{Teorioita elli-sanueen etymologiasta ja merkityksen- kehityksest $\ddot{a}$}

Ilmeistä on, että elki-sanue ei kuulu alkuaan omaperäiseen sanastoomme. Sukukielissämme elki-sanue näyttää rajoittuvan ainoastaan

\footnotetext{
4 Juho Kujola, Lyydiläismurteiden sanakirja. Helsinki 1944.

s Lauri Kettunen, Lõunavepsa häälik-ajalugu I-II. Tartu 1922. I ss. 7, 41, 43, 53 ; II ss. $4,16$.

- August Ahlqvist, Anteckningar i nordtschudiskan; Acta Societatis scientiarum Fennicae. Tomus VI. Helsinki 1861. S. 82.

? Suomen kielen etymologinen sanakirja (SKES) I. Helsinki 1955.
} 
itämerensuomalaisiin kieliin, lähinnä karjala-aunukseen ja vepsään, kuten edellä on esitetty.

Jalo KALima on selittänyt elki-sanueen balttilaisperäiseksi, vrt. liett. elgesỹs, gen. eĩgesio 'käytös' (Benehmen, Betragen, Aufführung), elgimasis 'käytös, menettely' (Benehmen, Verhalten) ja ẽ $\tilde{l}$-tis 'käyttäytyä' (sich benehmen, sich betragen, sich aufführen). KALIMAn mielestä lainanantajamuotona on ollut jokin liett. eĩgtis-verbin johdos. Elki vastaa hänen mukaansa tarkoin kantasanaa elg-. Hän arvelee myös, että ele, eleet saattaisi olla sekaantuma, johon elki on vaikuttanut, mutta jättää asian kuitenkin ratkaisematta. ${ }^{8}$

Siihen käsitykseen, että elki on balttilaisperäinen, näyttää, tosin epävarmasti, yhtyvän myös Y. H. TorvoNEN ${ }^{9}$, samoin Lauri HAKULINEN. ${ }^{10}$

T. E. KaRSTEN on kahdessakin teoksessaan, "Germanisch-finnische Lehnwortstudien" ja "Finnar och germaner I", käsitellyt elki- ja ilkë̈-sanueiden etymologiaa. Näissä tutkimuksissaan hän seikkaperäisten vertailujen avulla tahtoo osoittaa, että elki- ja ilkë̈- t. ilkiäsanueet kuuluvat läheisesti yhteen ja ovat germaanista alkuperää. KaRSTENin esittämän etymologian mukaan suomen ellii : eljen, elkiä ja ilkë̈, ilkiä, iljetä : ilkenen sekä viron ilge ja ilgema kuuluvat etymologisesti yhteen, kun taas esim. vepsän elgendan ja elgetôin olisi pidettävä näistä erillään. KARsTteN on sitä mieltä, että nämä sanueet ovat johdettavissa muinaisgermaanisesta *elhia- (l. *elgia-) muodosta (vielä varhaisempi muoto olisi *elxia), joka on pohjana mm. muinaisskandinavian $i l l r$-sanassa 'omoralisk, syndig; fientlig, ond, skadlig; oangenäm ; dålig, av ringa värde ; svår ; knapp, sparsam' ja muinaisruotsin adverbissa illa (= isl. illa) 'på ett sätt som vållar obehag, skada, svårligen, illa, på orätt sätt'. Hän esittää edelleen, että mgerm. "elhia-vartalosta olisi kehittynyt muinaisyläsaksan ilgi 'fames', ja todennäköisesti samaan yhteyteen kuuluisivat vielä liettuan álkti 'hungern', alǔči 'fames' sekä iirin elc, olc ("elkos, *olkos) 'schlecht'. Tässä olisi siis osoitettavissa merkityksenkehitys: 'Hunger' -

${ }^{8}$ Jalo Kalima, Itämerensuomalaisten kielten balttilaiset lainasanat. Helsinki 1936. Ss. 2, 55, 68, $84-85,92-93$.

SKES.

10 Lauri Hakulinen; Suomen kielen rakenne ja kehitys. Toinen korjattu painos. Keuruu 1961. S. 324. 
'schlecht', jota KARSTEN vielä vertaa erääseen kreikan kielen vastaavaan edustukseen. ${ }^{11}$

Björn CoLLINDER käsittelee myös näiden sanueiden etymologiaa teoksessaan "Die urgermanischen Lehnwörter im Finnischen". Hän lähtee Karstenin teorian pohjalta ja näyttää osittain yhtyvän siihen. Hän ei kuitenkaan hyväksy edellä esitettyä Karstenin teorian kehittelyä kokonaisuudessaan, vaan esittää eriäviä mielipiteitä mm. merkityksenkehityksestä. Lopuksi CoLLINDER asettaakin kyseenalaiseksi,

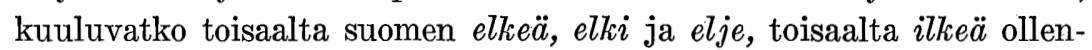
kaan etymologisesti yhteen. Hän pitää mahdollisena sitä, että elki, elje (elkeä) kuuluisivat yhteen ele, eleet -sanan kanssa, jota hän taas pitää elä̈̈-verbistä johtuneena verbaalisubstantiivina. ${ }^{12}$

Suomen elki-sanueen etymologiaan viittaavat myös esim. Elof HELLquisT (Svensk etymologisk ordbok I, 1939, s. 402), Ferdinand Holthausen (Vergleichendes und Etymologisches Wörterbuch des Altwestnordischen, 1948, s. 142) ja Jan DE VRIEs (Altnordisches etymologisches Wörterbuch, 1961, s. 285), mutta kaikki nämä viittaukset yhtyvät lähinnä Karstenin teoriaan eivätkä tarjoa mitään olennaisesti uutta.

Mainita ehkä kannattaa vielä Nikolai ANDERssovin esittämä teo-

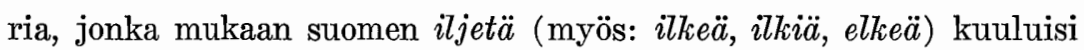

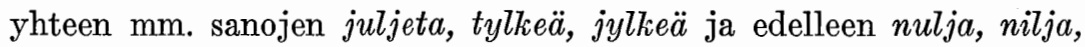

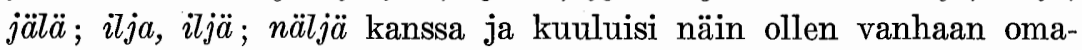
peräiseen sanastoomme. ${ }^{13}$ Tämä teoria ei kuitenkaan liene saanut kannatusta.

Suomen kielen elki-sanueen etymologiasta on siis olemassa lähinnä kaksi perusteltua teoriaa. Toisen mukaan elki on balttilaisperäinen, toisen mukaan se liittyy läheisesti $i 7 k e \ddot{a}$-sanueeseen ja on germaaninen lainasana.

Elki- ja ilkeä-sanueet ovat epäilemättä monin tavoin toisilleen läheiset. Tämän rinnakkaisuuden ei kuitenkaan välttämättä tarvitse

11 T. E. Karsten, Germanisch-finnische Lehnwortstudien. Helsinki 1915. Ss. 79—80, 144, 194, 241; Finnar och germaner I. Helsinki 1943. S. 79.

12 Björn Collinder, Die urgermanischen Lehnwörter im Finnischen. Uppsala 1932. Ss. $67,187-188$.

${ }^{13}$ Nikolai Andersson, Wandlungen der anlautenden dentalen Spirans im Ostjakischen; Mémoires de l'Académie Impériale des Sciences de St.-Pétersbourg 740 2. St.-Pétersbourg 1893. Ss. 128, 220. 
merkitä sitä, että kummankin sanueen alkuperä olisi yhteinen. Niinpä edellä käsitellyn aineiston perusteella voinee ilmeisesti pitää mahdollisena sitä, että elki-sanue ainakin pääasiassa on balttilaisperäinen ja sen etymologisena lähtömuotona on jokin liettuan eígtis 'käyttäytyä' verbin johdos. Sanueen merkityksenkehityksen selittäminen ei nähtävästi tuottane ylivoimaisia vaikeuksia. Tällöin on vain ajateltava, että elki-sanueen merkitys on vähitellen kehittynyt negatiiviseksi, mikä sinänsä ei kielessä ole outo ilmiö.

Karjala-aunuksen ja vepsän 'ymmärtämistä' merkitsevät verbit (ellentää, ellendeä, ellendiä ja elgeta) ja näihin läheisesti liittyvät ilmaukset voidaan selittää liettuan ẽ gtis 'käyttäytyä' verbin pohjalta. Karjalan verbit elgiändyö, elgävÿ̈ 'kyllästyä', elgäillä 'iljeksyä' ja elgäitteä, elgävyttiä, ellätä 'kyllästyttää, inhottaa, etoa, ellottaa' sekä adjektiivi ellotoi 'älytön' ja adverbi ellottomuten 'älyttömästi' ynnä vepsän elgetoi 'älytön', etelävepsän öugotō 'kunnoton, kelvoton' ja elgeitelob, elgensõitab 'iljettää, inhottaa' ovat tuskin erotettavissa $e l k i$-sanueesta, ja niinpä näidenkin voinee katsoa tukevan sitä selitystä, että sanueen merkitys on vähitellen muuttunut negatiiviseksi. Tässä yhteydessä on mainittava myös suomen elloa, ellottaa, ellostaa ja ellostella, jotka merkitsevät jokseenkin samaa kuin juuri esitetyt karjalan ja vepsän verbit. Nämä jonkin vastenmielisen aiheuttaman pahan olon tunnetta kuvaavat ('oksettaa, etoa, inhottaa, tympäistä') verbit ovat kielessämme lähinnä itämurteiden sanoja. $\mathrm{Ne}$ tuntuvat deskriptiivisiltä (vrt. ällöttä̈ä), eikä niitä voitane etymologisesti yhdistää elki-sanueeseen.

Elki-sanueen merkityksenkehitys ei ole suoraviivainen eikä irrallinen ilmiö, vaan epäilemättä ilke ä-sanue on siihen huomattavasti vaikuttanut; vaikutusta on yhtä ilmeisesti tapahtunut myös päinvastaiseen suuntaan. Vrt. sellaisia rinnakkaisuuksia kuin elkeä, elkiä $\sim i l k e \ddot{a}$, ilkï̈; pahan- t. häijynelkinen pahan- t. häijynilkinen; -elkisyys -ilkisyys; elkivalta ilkivalta jne. Sanueiden merkitysten rinnakkaisuuden ei kuitenkaan välttämättä tarvitse ajatella todistavan niiden yhteistä alkuperää. Pikemminkin saattaa ajatella, että suomen kielessä merkityksiltään jo ennestäänkin toisilleen läheiset sanueet ovat kehittyneet yhä rinnakkaisemmiksi. Samalla kuitenkin uudempi germaanista alkuperää oleva $i l k e \ddot{a}$-sanue on vallannut alaa, kun taas vanhemman balttilaisperäisen elki-sanueen käyttöalue on supistunut. $E l k i$-sanue esiintyy nykyisin etupäässä länsi-Suomessa, 


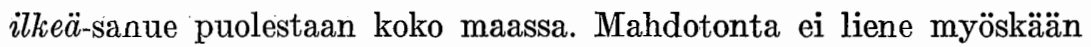
ajatella, että $i l k e \ddot{a}$-sanue olisi läntisissä sukukielissämme (viro, vatja, liivi) sulattanut itseensä näissä mahdollisesti esiintyneen balttilaisperäisen elki-sanueen, joka itäisissä, karjala-aunuksessa ja vepsässä, vielä on säilynyt.

\section{AImo HaKanEN : The 'elki' word group in Finnish}

The elki word group in Finnish, which is rare in modern literary usage, is negative of its nature: i.e. words and phrases belonging to it describe something bad, or something having an unpleasant property, or an unpleasant action. The nouns that occur most frequently are elje and ellei (usually plural elkeet, eljet) meaning 'bad habit or intention or deed', 'trick', 'practical joke', 'sharp practice', 'low trick', 'special habit (esp. stirring up scandal)', 'characteristic', 'caprice' and the adjectives pahanelkinen and häijynellinen - 'naughty', 'malicious', 'mischievous'.

Examples of the elki group are found rather frequently in literary Finnish from Agricola onwards. These are the noun elki and the compound elkivalta 'evil', 'maliciousness', 'wickedness' and their derivatives.

The adjective elliä is rather rare, but on the other hand its near-synonyms pahanelkinen, häijynelkinen and sen elkinen are found frequently and sometimes mean 'of this kind', 'to that effect', 'such'. Of its general nature, the elki group in old literary Finnish is negative.

Information available in dictionaries is of relatively recent date, the earliest being in Juslenius' dictionary (1745).

Expressions belonging to the elki group are rather widely used in the western dialects of Finland - the most frequent forms being elje and elki (usually elkeet, eljet) and derivatives thereof.

Meaning is substantially the same as in literary usage, perhaps a little less restricted.

In some districts of Varsinais-Suomi the dialect word elju (usually plural eljut) is found, meaning 'bad habit', 'trick', 'practical joke', 'caprice'; elje, elki and its derivatives eljuinen - 'ragging', 'trouble-making', eljutella - 'to tease, to be capricious', eljuttelija - 'a schemer' and eljutteleminen - 'mischiefmaking', 'maliciousness'.

In related languages the elki group seems to be limited to Karelian-Olonets and Veps. It is true that in Lappish there exists also the verb axije - 'to remember', 'to understand' but this is probably a loan from Karelian-Olonets.

There are really two established theories about the etymology of the ellki group in Finnish. Jalo Kalima thinks that it is of Baltic origin - the original form being the Lithuanian verb elgtis meaning 'to behave'. According to T. E. Karsten elki is closely related to ilkeä 'evil', 'bad', 'wicked' and is of Germanic origin (<< old Germanic *elhia-, *elgia- <*el $i a)$.

It is of course evident that the elki and ilkeea groups in Finnish are in many 
ways close to one another, but this proximity does not necessarily mean that the two groups have the same etymology. The material studied would seem to support the view that the elki group is of Baltic origin and that its meaning has gradually become more negative.

In part this development has certainly been influenced by the illeeä group, of western origin and negative by nature, which as a later arrival has gained ground, while the use of the older elki group of Baltic origin has dwindled. 